http://dx.doi.org/10.1590/1678-4162-7530

Arq. Bras. Med. Vet. Zootec., v.67, n.5, p.1205-1209, 2015

\title{
Detection of Mycobacterium avium subsp. paratuberculosis in a cattle/pudu interface
}

\author{
[Detecção de Mycobacterium avium subsp. paratuberculosis em \\ uma interface gado/pudu] \\ M. Salgado ${ }^{1}$, O.A. Aleuy ${ }^{2}$, I.A. Sevilla ${ }^{3}$, E. Troncoso ${ }^{1}$ \\ ${ }^{1}$ Instituto de Bioquímica y Microbiología - Facultad de Ciencias - Universidad Austral de Chile, Chile \\ ${ }^{2}$ Centro de Rescate de Fauna Silvestre (CEREFAS) - Facultad de Ciencias \\ Veterinarias - Universidad Austral de Chile, Chile \\ ${ }^{3}$ Instituto Vasco de Investigación y Deasarrollo Agrario (NEIKER) - Derio, España
}

\begin{abstract}
Mycobacterium avium subsp. paratuberculosis (Map) is the etiological agent of paratuberculosis. In Chile, information about Map isolation from both domestic ruminant and wildlife species has been accumulating, but it has to be extended to other species. The present study focuses specifically on one wild grazing species, the pudu (Pudu puda), one of the less known South American deer considered an endangered species that shares pastures with cattle in southern Chile, where the greatest part of the country's dairy cattle population is located. Convenient samples from 3 pudus were collected from one dairy farm where Map infection had previously been confirmed in cattle. All three pudus shed the bacterium in feces and the isolates are the same type of Map as described for cattle. This study represents the first case report of Map isolation in the pudu captured from the wild. It is also the first documented association between a Map-infected dairy herd and free-ranging wildlife species, such as pudu in the Los Ríos region, Chile. Since interspecies transmission of Map and other pathogens from livestock to pudu has already been demonstrated, the results from this study suggest that this free-ranging wildlife specie, inhabiting a dairy district in southern Chile, might represent another case of spillover host.
\end{abstract}

Keywords: paratuberculosis, Map, wildlife, infection, spillover

\section{RESUMO}

O agente etiológico da paratuberculose é o Mycobacterium avium subsp. paratuberculosis (Map). No Chile, já foi gerada informação do isolamento do Map em ruminantes domésticos e em algumas espécies selvagens, porém essa informação deve ser expandida a outras espécies. O presente estudo está focado na espécie selvagem herbívora, o Pudu (Pudu puda), que é considerado um dos cervos menos conhecidos da América do Sul, e que está em extinção. Essa espécie compartilha as pastagens com o gado no sul do Chile, local do país onde está concentrada a maior parte do rebanho leiteiro. Foram obtidas amostras de 3 pudus de uma fazenda de gado leiteiro, onde previamente havia sido confirmada a infecção por Map em bovinos. Os três pudus eliminavam a bactéria nas fezes, e os isolados fecais foram do mesmo tipo do Map relatado para os bovinos. Este estudo representa o primeiro relato de caso de isolamento do Map em pudu em vida silvestre. Também é a primeira associação documentada entre um rebanho leiteiro infectado com Map e a infecção de uma espécie silvestre de vida livre, tal como o pudu na região de Los Ríos, no Chile. A transmissão interespécies do Map, do mesmo modo que de outros patógenos de ruminantes para o pudu, já foi demonstrada, assim os resultados deste estudo sugerem que essa espécie de vida extensiva, que habita a mesma região leiteira no sul do Chile, pode representar mais um caso de repercussão ao hospedeiro.

Palavras-chave: paratuberculose, Map, animais selvagens, infecção, repercussão

Recebido em 2 de abril de 2014

Aceito em 5 de agosto de 2015

E-mail: miguelsalgado@uach.cl 


\section{INTRODUCTION}

Mycobacterium avium subsp. paratuberculosis (Map) is the etiological agent of paratuberculosis, an infectious bacterial disease characterized by granulomatous enteritis, diarrhea, loss of body weight and death.

The infection primarily affects domestic ruminants, but it has also been reported to affect wild ruminants and, in the last two decades, nonruminant wildlife species have been included in the wide range of host species (Dukes et al., 1992; Buergelt and Ginn, 2000; Beard et al., 2001; Corn et al., 2005). These findings have raised the question of whether the natural host range, experiencing active, not passive infection, might be wider than previously thought, thereby suggesting that the epidemiology of this disease is more complex than previously realized. Since a clinically infected cow may shed over $10^{8}$ bacteria per gram of feces (Cranwell, 1997; Whittington et al., 2000), the likelihood of wildlife herbivores sharing pasture with infected cattle taking in bacteria through the ingestion of fecally contaminated grass is high. Therefore, the occurrence of Map infected wildlife species found in farming areas suggests at least a potential transmission of Map from livestock to wildlife.

Since 1958 information about Map isolation in Chile from both domestic ruminants (Grinbergs and Caorsi, 1958; Zamora et al., 1975; Salgado et al., 2007) and wildlife (Salgado et al., 2009; Salgado et al., 2011) has been growing, underlining the need to add new information in order to understand the epidemiology of paratuberculosis.

The aim of the present study was to determine the existence of Map infection in a free-ranging wildlife species such as pudu (Pudu puda) in southern Chile, where most of the Chilean dairy cattle population is located.

\section{MATERIALS AND METHODS}

The wildlife species sampled in this study were selected under a convenience criterion of being captured in farms located in the Los Ríos region, an area where the herd Map infection rate has been estimated to be high (Van Schaik et al., 2007).
In May 2009, three pudus where sampled for Map at the Wildlife Rehabilitation Center (CEREFAS), Universidad Austral de Chile, where they were brought with evidence of dog attack lesions from a dairy farm with a history of bovine paratuberculosis, where fecal culture prevalence was estimated to be $10 \%$ in a survey previously carried out by the authors (unpublished data). In the CEREFAS they were kept in individual pens during their rehabilitation and sampled for Map isolation before being released into the wild. Fecal material was aseptically collected directly from the rectum into sterile, disposable bottles under manual restriction of the animals and submitted to the paratuberculosis laboratory, Instituto de Bioquímica y Microbiología, Facultad de Cienicas, Universidad Austral de Chile.

The fecal samples were processed as indicated by the manufacturers' protocols and inoculated into ParaTB MGIT medium tubes (Becton Dickinson, Sparks, MD). Each tube contained $7 \mathrm{~mL}$ of modified Middlebrook $7 \mathrm{H} 9$ broth base with mycobactin $\mathrm{J}$ and a fluorescent oxygen indicator embedded in silicon at the bottom of the tube. Each tube was supplemented with $800 \mu \mathrm{L}$ of MGIT ParaTB supplement (Becton Dickinson, Sparks, MD), $500 \mu \mathrm{L}$ of egg yolk suspension (Becton Dickinson, Sparks, MD), and $100 \mu \mathrm{L}$ of VAN cocktail (SIGMA), resulting in final concentrations of $10 \mu \mathrm{g} / \mathrm{mL}$ vancomycin, $40 \mu \mathrm{g} / \mathrm{mL}$ amphotericin B and $60 \mu \mathrm{g} / \mathrm{mL}$ nalidixic acid. Each inoculated MGIT tube was introduced into the BACTEC MGIT 960 incubator and left at $37^{\circ} \mathrm{C}$ for 49 days.

After completion of the incubation period, the positive tubes were removed from the BACTEC incubator and DNA was extracted for real-time PCR testing. In order to obtain a sufficient amount of quality DNA material for molecular confirmation from the liquid culture, the method for mycobacterial DNA isolation first reported by van Soolingen et al. (1991), using cethyl trimethyl ammonium bromide (CTAB) was followed. During the last step the pellet was resuspended in $25 \mu \mathrm{L}$ of $1 \mathrm{x}$ TE buffer and kept at $-20^{\circ} \mathrm{C}$ and submitted to NEIKER-Tecnalia, Spain.

The samples were subjected to a triplex real-time PCR targeting IS900 (Herthnek et al., 2006) and ISMAP02 sequences of Map, as well as an 
internal amplification control (IAC) (Sevilla et al., 2009). The $50 \mu \mathrm{L}$ PCR mixture contained $5 \mu \mathrm{L}$ of template DNA, 1x TaqMan Universal MasterMix (Applied Biosystems, CA), 0.4 $\mu \mathrm{M}$ (each) of primers co-amplifying ISMAP02 and the IAC, $0.3 \mu \mathrm{M}$ (each) of IS900 primers, $0.2 \mu \mathrm{M}$ (each) of ISMAP02, IAC and IS900 probes and $2 \mu \mathrm{L}$ of IAC template DNA (Sevilla et al., 2009). Reactions were carried out in an Applied Biosystems 7500 Real-Time PCR system under the following standard conditions: one cycle at $95^{\circ} \mathrm{C}$ for $10 \mathrm{~min}$ and 45 cycles with two steps, $95^{\circ} \mathrm{C}$ for $15 \mathrm{~s}$ and $60^{\circ} \mathrm{C}$ for $1 \mathrm{~min}$. A negative and a positive (ATCC 19698 reference strain) DNA control were included with each plate.

In order to discriminate Map strains obtained from cattle, Map strains from pudu confirmed by IS900 and ISMAP02 real-time PCR were subjected to MIRU-VNTR typing. MIRU-VTNR typing was performed using 5 loci identified as polymorphic for Map $\mathrm{K} 10$ and called MIRU-VNTR 292, X3, 25, 47 and 3 (from locus 1 to locus 5) as described (Thibault et al., 2007). Primers designed to target flanking regions of the MIRU-VNTRs and the conditions of the PCR amplification were carried out as described (Thibault et al., 2007). Briefly, the PCR mixture for each MIRU-VNTR locus comprised $5 \mu \mathrm{L}$ of template DNA, $1.5 \mathrm{mM}$ of magnesium chloride,
$1 \mu \mathrm{L}$ of dimethyl sulfoxide (Sigma, St. Louis, Mo) (except for locus 2), $1 \mu \mathrm{M}$ (each) of primers, $50 \mu \mathrm{M}$ of (each) dATP, dCTP, dGTP, and dTTP and $1.25 \mathrm{U}$ of Platinum Taq (Invitrogen Ltd., Paisley, UK) in a final volume of $25 \mu \mathrm{L}$. Reactions were carried out using a GeneAmp 9600 PCR system (Applied Biosystems, Foster City, CA, USA). PCR conditions were as follows: 1 cycle of $5 \mathrm{~min}$ at $94^{\circ} \mathrm{C} ; 30$ cycles of $30 \mathrm{~s}$ at $94^{\circ} \mathrm{C}, 30 \mathrm{~s}$ at $58^{\circ} \mathrm{C}$, and $30 \mathrm{~s}$ at $72^{\circ} \mathrm{C}$; and 1 cycle of 7 min at $72^{\circ} \mathrm{C}$. To detect differences in repeat numbers, the PCR products were analyzed by electrophoresis using $1.5 \%$ agarose gels. Repeat numbers (alleles) were determined according to amplified fragment sizes using Gel Doc 2000 (Biorad, Herefordshire, UK) and Quantity One 4.2.1. software (Biorad) for fragment size calculation.

\section{RESULTS}

All three examined pudus were fecal culture positive for Map, confirmed molecularly through real-time PCR. All isolates tested belonged to the same MIRU-VNTR type. All showed 4 repeats for TR292 (locus1) in contrast to the 3 repeats typical of the reference strain K10 (Table 1). The number of repeats found in the remaining loci was identical to that of the $\mathrm{K} 10$ strain.

Table 1. MIRU-VNTR results by type of samples

\begin{tabular}{cccccccccc}
\multicolumn{1}{c}{ Strains } & $\begin{array}{c}\text { no. of repeats } \\
\text { locus1 } \\
\text { TR292 }\end{array}$ & $\begin{array}{c}\text { locus2 } \\
\text { TRX3 }\end{array}$ & $\begin{array}{c}\text { locus3 } \\
\text { TR25 }\end{array}$ & $\begin{array}{c}\text { locus4 } \\
\text { TR47 }\end{array}$ & $\begin{array}{c}\text { locus5 } \\
\text { TR3 }\end{array}$ & $\begin{array}{c}\text { locus6 } \\
\text { TR7 }\end{array}$ & $\begin{array}{c}\text { locus7 } \\
\text { TR10 }\end{array}$ & $\begin{array}{c}\text { locus8 } \\
\text { TR32 }\end{array}$ & Host \\
\hline In house control & 4 & 2 & 3 & 3 & 2 & 2 & 2 & 8 & Cow \\
1 & 4 & 2 & 3 & 3 & 2 & 2 & 2 & 8 & pudu \\
2 & 4 & 2 & 3 & 3 & 2 & 2 & 2 & $\mathrm{~N}$ & pudu \\
3 & 4 & 2 & 3 & 3 & 2 & 2 & 2 & $\mathrm{~N}$ & pudu \\
k10 (ATCC control) & 3 & 2 & 3 & 3 & 2 & 2 & 2 & 8 & \\
\hline
\end{tabular}

\section{DISCUSSION}

The first isolation of Map from a captive pudu was reported in 1985 (De Meurichy et al., 1985). Later, Vansnick et al. (2005) reported positive serological results (ELISA) in two pudus in a zoo. Finally, in Chile González et al. (2011) described the pathology of a pudu case, showing lesions and histopathology consistent with paratuberculosis, yet no Map isolation was informed.

This study represents the first published report on isolation of Map in a pudu captured from the wild. It is also the first documented association between a Map-infected dairy herd and a freeranging wildlife species, such as pudu in an important cattle dairy district in De Los Ríos region, Chile. 
The pudu is one of the less known South American deer and is considered an endangered species in accordance with the Red Book of the World Union for Nature (U.I.C.N.) and CITES Appendix 1 (Weber and González, 2003). The presence of cattle in protected areas (SilvaRodríguez et al., 2009), the fact that in Chile diseases other than paratuberculosis have been reported to be transmitted from cattle to pudu (Pizarro-Lucero et al., 2005), and the wellknown susceptibility of deer to paratuberculosis (Mackintosh et al., 2004) suggests that paratuberculosis could constitute an additional threat to the pudu preservation.

Due to the lack of pathology information in the present study, the results only allowed us to state that the three animals shed the organism into the environment. However, based on the susceptibility of deer to paratuberculosis (Mackintosh et al., 2004), this finding could be interpreted as a likely active infection, rather than a passive transient infection.

The importance of the infection in wild animals has been focused on regarding them as a reservoir of infection and not considering the significance of the huge amount of Map that livestock operation sheds into the environment. This hypothesis is also supported by the molecular typing results. The lack of variation among strains from domestic ruminants and strains obtained from pudu is indicative of interspecies transmission. However, it should be taken into consideration that the little genotypic variation of these isolates could also indicate that Map exhibits little diversity or simply that the discriminatory power of the technique used is not suitable to reveal heterogeneity within these bacterial populations.

\section{CONCLUSIONS}

The new scope discussed in this article ought to be taken into account when planning a disease control program in domestic livestock. In the case of the pudu in Chile, despite the small number of animals studied, this species seems to be true livestock spillover hosts, inhabiting the same grazing environment.

\section{ACKNOWLEDGMENTS}

This work was supported by the Biochemistry and Microbiology Department, Faculty of Sciences, Universidad Austral de Chile, Valdivia, Chile; and Instituto Vasco de Investigación y Deasarrollo Agrario (NEIKER) Derio, Spain, and Proyecto FIC-R 2008 EQU-08.

\section{REFERENCES}

BEARD, P.; DANIELS, M.J.; HENDERSON, D. et al. Paratuberculosis infection of non-ruminant wildlife in Scotland. J. Clin. Microbiol., v.39, p.1517-1521, 2001

BUERGELT, C.D.; GINN, P.E. The histopathologic diagnosis of subclinical Johne's disease in North American bison (Bison bison). J. Vet. Microbiol., v.77, p.325-331, 2000.

CORN, J.L.; MANNING, E.J.; SREEVATSAN, $\mathrm{S}$. et al. Isolation of Mycobacterium avium subsp. paratuberculosis from free ranging birds and mammals on livestock premises. J. Appl. Environ. Microbiol., v.71, p.6963-6967, 2005.

CRANWELL, M.P. Johne's disease: past and present. Cattle Pract., v.5, p.217-223, 1997.

DE MEURICHY, W.; PORTAELS, F.; HOORENS, J. et al. Outbreak of a paratuberculosis-like disease in a captive pudu herd (Pudu pudu). In: VERHANDLUNGSBERICHT DES 27 INTERNATIONALEN SYMPOSIUM ÜBER DIE ERKRANKUNGEN DER ZOOTIERE, 9 June-3 July, 1985, St. Vincent/Torino, Italy, p.469-480.

DUKES, T.W.; GLOVER, G.J.; BROOKS, B.W. et al. Paratuberculosis in Saiga Antelope (Saiga tatarica) and experimental transmission to domestic sheep. J.Wildl. Dis., v.28, p.161-70, 1992.

GONZÁLEZ-ACUÑA, D.; NEIRA-RAMIREZ, V.; MORENO-SALAS, L. et al. First report of paratuberculose in Southern Pudu deer (Artyodactila: Cervidae). Arq. Bras. Med. Vet. Zootec., v.63, p.1025-1027, 2011.

GRINBERGS. J.; CAORSI, I. Enfermedad de Johne o paratuberculosis en Chile. Pub. Cient. de la Univ. Austral de Chile, v.4, p.9-13, 1958. 
HERTHNEK, D.; ENGLUND, S.; WILLEMSEN, P.T.J. et al. Sensitive detection of Mycobacterium avium subsp. paratuberculosis in bovine semen by real-time PCR. J. Appl. Microbiol., v.100, p.1095-1102, 2006.

MACKINTOSH， C.G.; DE LISLE， G.W.; COLLINS, D.M. et al. Mycobacterial diseases of deer. New Zeal. Vet. J., v.52, p.163-174, 2004.

PIZARRO-LUCERO, J.; CELEDÓN, M.O.; NAVARRO, C. et al. Identification of a pestivirus isolated from a free-ranging pudu (Pudu puda) in Chile. Vet. Rec., v.157, p.292294, 2005.

SALGADO, M.; HERTHNEK, D.; BÖLSKE, G. et al. First isolation of Mycobacterium avium subsp. paratuberculosis from wild guanacos (Lama guanicoe) on Tierra del Fuego island. J. Wildl. Dis., v.45, p.295-301, 2009.

SALGADO, M.; KRUZE, J.; COLLINS, M.T. Diagnosis of paratuberculosis by fecal culture and ELISA on milk and serum samples in two types of Chilean dairy goat herds. J. Vet. Diagn. Invest., v.19, p.99-102, 2007.

SALGADO, M.; MANNING, E.J.B.; MONTI, G. et al. "Hares in Chile: a different lagomorph reservoir for Mycobacterium avium subsp. paratuberculosis?". J. Wildlife Dis., v.47, p.734738, 2011.

SEVILLA, I.; GARRIDO, J.M.; SÁNCHEZ, I. et al. Mycobacterium avium subsp. paratuberculosis detected and quantified using different DNA extraction and real-time amplification methods in artificially inoculated fecal samples from cattle. In: $10 \mathrm{TH}$ INTERNATIONAL COLLOQUIUM ON PARATUBERCULOSIS, 9th-14th August, 2009, Minneapolis, MN, USA.

SILVA-RODRÍGUEZ， E.A.; VERDUGO, C.; ALEUY, O.A. et al. Evaluating mortality sources for the Vulnerable pudu (Pudu puda) in Chile: implications for the conservation of a threatened deer. Oryx., v.44, p.97, 2009.
THIBAULT, V.C.; GRAYON, M.; BOSCHIROLI, M.L. et al. New variable-number tandem-repeat markers for typing Mycobacterium avium subsp. paratuberculosis and $M$. avium strains: comparison with IS900 and IS1245 restriction fragment length polymorphism typing. J. Clin. Microbiol., v.45, p.2404-2410, 2007.

VAN SCHAIK, G.; HARO, F.; MELLA, A. et al. Bayesian analysis to validate a commercial ELISA to detect paratuberculosis in dairy herds of southern Chile. Prev. Vet. Med., v.79, p.5969, 2007.

VAN SOOLINGEN, D.; HERMANS, P.W.; DE HAAS, P.E. et al. Occurrence and stability of insertion sequences in Mycobacterium tuberculosis complex strains: evaluation of an insertion sequence-dependent DNA polymorphism as a tool in the epidemiology of tuberculosis. J. Clin. Microbiol., v.29, p.25782586, 1991.

VANSNICK, E.; VERCAMMEN, F.; BAUWENS, L. et al. A survey for Mycobacterium avium subspecies paratuberculosis in the Royal Zoological Society of Antwerp. Vet. J., v.170, p.249-256, 2005.

WEBER, M.; GONZÁLEZ, S. Latin American deer diversity and conservation: a review of status and distribution. Ecoscience, v.10, p.443454, 2003.

WHITTINGTON, R.J.; REDDACLIFF, L.; MARSH, I. et al. Temporal patterns and quantification of excretion of Mycobacterium avium subsp paratuberculosis in sheep with Johne's disease. Aust. Vet. J., v.78, p.34-37, 2000.

ZAMORA, J.; KRUZE, J.; SCHIFFERLI, C. Paratuberculosis ovina. Primer caso descrito en Chile. Arch. Med. Vet., v.7, p.15-17, 1975. 